\title{
Resandets teknologier och känslor
}

\author{
Finländska resenärer $i$ det tidiga I80o-talets Europa
}

RESENÄrER SOM I BÖRJAN AV I80o-talet färdades från Finland till andra delar av Europa kan i viss mening sägas ha förflyttat sig till en nära framtid. I de västliga delarna av Kontinentaleuropa och på de brittiska öarna kunde de se och uppleva mycket sådant som ännu inte var en del av människors erfarenhetsvärld i hemlandet. Redan resandet i sig väckte en mångfald av känslor hos resenärerna, likaså de varierande besöksmål och sevärdheter som de bekantade sig med på de för tidsperioden typiska långa rundresorna. I min essä fokuserar jag särskilt på de erfarenheter och känslouttryck som knyter an till den teknologi som gjorde resandet möjligt: olika färdmedel, trafiklösningar och den infrastruktur som över lag var en förutsättning för rörligheten. Hur färdades resenärerna i praktiken från en ort till en annan och hur kommenterade de resandets teknologi? Hur kändes det att resa i början av I8oo-talet?

Tiden kring sekelskiftet I80o och det nya århundradets första hälft var en brytningstid för resandet, med ständigt växande passagerarmängder och nya trafiksystem samt tekniska tillämpningar. ${ }^{1}$ Till de betydande förändringar som påverkade resandet vid denna tid hörde att segelfartygen delvis ersattes av ångfartyg och att det europeiska järnvägsnätverket stegvis byggdes ut. Under resor i Europa kunde

Essän baserar sig på forskning som jag har gjort för en fackbok om resande: Pikisaaresta Pariisiin. Suomalaismatkaajien kokemuksia I8oo-luvun Euroopassa, Helsinki: Gaudeamus 2020.

I. Om att undersöka trafiksystemens historia ur ett tekonologihistoriskt perspektiv, se Marko Nenonen, "Liikennehistorian tutkimus Suomessa - näkökohtia menneestä ja tulevasta", Tekniikan Waiheita 36, 2018:3, s. 39-56, https://journal.fil tekniikanwaiheita/article/view/82368 (hämtad I5/12 2020). 
finländare bekanta sig med ångkraftens tillämpningar - ångfartyg och tåg - innan det blev möjligt i Finland.

Förutom med nya färdmedel och ett trafiknätverk som var mer utvecklat än i hemlandet konfronterades finländska resenärer som reste runt i Europa med olika tekniska uppfinningar, apparater och förevisningar av nya teknologier. I essän behandlar jag också möten med sådana teknologiska tillämpningar, till exempel den optiska telegrafen, panoramat och dioramat. Med teknologi syftar jag på ett system av kunskaper och färdigheter med hjälp av vilka man eftersträvar att nå vissa mål. Teknik förstår jag som de verktyg, anläggningar och metoder som användes för att nå målet. ${ }^{2}$

Essän behandlar tiden kring sekelskiftet I80o och det nya seklets första årtionden, som särskilt i europeisk historieskrivning har betecknats som revolutionernas och romantikens tidevarv. Uppfattningarna kan variera beroende på definitioner och perspektiv, men åtminstone stod Europa vid denna tid på tröskeln till den moderna tiden. De fenomen och innovationer som associeras med moderniseringen spreds ändå ojämnt. Den ojämna utvecklingen i olika delar av Europa avspeglas i den takt i vilken nya teknologier och tillämpningar togs i bruk, i möjligheterna att hålla sig uppdaterad om aktuella händelser över lag och i olika förutsättningar för delaktighet i politiska beslutsprocesser. I början av I8oo-talet var Finland på många sätt en europeisk periferi - en glest befolkad och fattig region utan betydande urbana centrum. Tidningsoffentligheten i Finland var anspråkslös i jämförelse med många andra länder och nådde endast en liten del av befolkningen. Därtill sammanträdde - efter Borgå lantdag I809 - inget representativt organ i storfurstendömet Finland under 180o-talets första hälft, utan landet administrerades av byråkrater.

Källmaterialet för essän består av dagböcker, brev och reseskildringar skrivna på svenska, av personer som var födda eller bosatta på det område som i dag utgör Finland vid tidpunkten för sin resa. ${ }^{3}$ En

2. Nenonen, "Liikennehistorian tutkimus Suomessa", s. 39. I vardagligt språk är betydelseskillnaden mellan de två termerna inte nödvändigtvis stor.

3. När det gäller tiden kring sekelskiftet $\mathrm{I} 800$ är det förvisso inte relevant att på ett allmänt plan särskilja Finland från det svenska riket i övrigt. Ur ett rörlighetsperspektiv innebar det faktum att resan måste inledas med att korsa havet från (dagens) Finland ändå att den medförde en större ansträngning för finländare än 
del av texterna har publicerats redan i samtiden, i dagstidningar eller i reseskildringar, en del är opublicerade eller har publicerats postumt. Till resenärerna hörde bland andra Frans Michael Franzén (I772-I847), docent vid akademin i Åbo, Immanuel Ilmoni (I797-I856), läkare och likaså akademialumn, konstnären Mathilda Rotkirch (I8I3-I842), filosofen och journalisten Johan Vilhelm Snellman (I806-I88I) och journalisten och författaren Zacharias Topelius (I8I8-I898). Resans längd, de mångskiftande besöksmålen och motiven bakom resorna varierade, men gemensamt för alla resorna var att de var relativt långa och riktade sig till Kontinentaleuropa - särskilt till dagens Tyskland och Frankrike, i vissa fall även till Storbritannien. Ilmoni och Rotkirch korsade också Alperna till Italien, Ilmoni reste ända till Sicilien. Reseskildringarna är från olika perioder, från I79o-talet till I850-talet, men i det här sammanhanget behandlar jag samtliga resenärer som representanter för den historiska epok som följde efter franska revolutionen.

Internationellt har intresset för resandets och turismens historia varit stort inom forskningen. Den moderna turismen föddes parallellt med industrialiseringen och demokratiseringen, processer som i Europas olika delar framskred i varierande takt. I Kontinentaleuropa kan drag av den moderna turismen skönjas under den tidsperiod som behandlas i den här essän. ${ }^{4}$ Från Finland reste man däremot ännu i början av I8oo-talet inte till andra delar av Europa i stora grupper längs reguljära rutter, och man anlitade inte organiserade resetjänster.

De personer på vilkas reseupplevelser jag baserar denna essä, reste inte heller i första hand i semestersyfte utan i huvudsak för arbete eller studier. Det handlade om långa rundresor som i de flesta fall räckte från flera månader upp till ett par år, under vilka man även bekantade sig med olika turistmål och bildade sig på andra sätt. Akademiskt utbildade manliga resenärer besökte exempelvis universitet och träffade utländska kolleger. Som konstnär var Mathilda Rotkirch

för invånarna i den västra riksdelen, som kunde nå Kontinentaleuropa efter en avsevärt kortare havsfärd eller via Danmark.

4. Till exempel James Buzard, som i sin forskning studerat särskilt britters resande, använder termen turism då han beskriver resande under det tidiga I80o-talet.James Buzard, The Beaten Track: European Tourism, Literature, and the Ways to 'Culture', I80o-I9I8, Oxford: Oxford University Press 1993. 
självklart intresserad av att se konst, men hon ritade och målade också själv under sin resa. Olika syften vävdes samman under resorna, som fortsatt präglades av drag från den europeiska grand tour-traditionen. ${ }^{5}$ Av denna orsak använder jag i den här essän termen resenär i stället för termen turist. ${ }^{6}$

\section{ÖVER HAVET}

För finländska resenärer som längtade till Västeuropa började färden av nödtvång med att korsa havet. Kring sekelskiftet $\mathrm{I} 800$ gick resor mot Kontinentaleuropa i praktiken längs varierande och individuella rutter. En del reste över Östersjön direkt mot den tyska kusten, medan andra först begav sig till Sverige eller Danmark och därifrån fortsatte till Tyskland genom Danmark. Varje resenär planerade sin egen rutt utifrån de resurser och möjligheter hen förfogade över. Eftersom det ännu inte fanns fartyg och rutter specifikt avsedda för passagerartrafik, var resenären beroende av handelsfartygens rutter och hastigheter. Den teknologi som människan hade utvecklat för resande fungerade ännu i början av I80o-talet i hög grad på naturens villkor. Vintertid isolerade den isbelagda Östersjön i praktiken Finland från all trafik till Kontinentaleuropa. Postrutten mellan Sverige och Finland genom den åländska skärgården trafikerades däremot också vintertid. ${ }^{7}$ Denna utnyttjade till exempel den engelske resenären Edward Daniel Clarke när han i december 1799 reste från Stockholm till Åbo. ${ }^{8}$

Segelfartygen utgör ett exempel på en av människan utvecklad teknologi som använder naturfenomen som drivkraft. Att resa på villkor som styrdes av vindarnas styrka och havens rörelser gjorde att resandet var oförutsägbart och delvis stod utanför mänsklig kontroll.

5. Närmare om detta, se Rantala, Pikisaaresta Pariisiin, s. I6-2I.

6. På engelska traveller; på finska matkaaja.

7. Christer Kuvaja, "Postvägen över Åland och dess betydelse I809-I9I4", Niklas Huldén \& Kasper Westerlund (red.), Maritimbistorisk konferens. Bottnisk kontakt XVI. Huvudtema: Kontakter och/eller konflikter, Korpo: Korpo Kulturgille r.f. 20I2, s. 9I-98, http://urn.fi/URN:NBN:fi-fe20I5I22I25044 (hämtad 3I/I 202I).

8. Edward Daniel Clarke, Travels in Various Countries of Europe, Asia and Africa.

Part the third: Scandinavia. Section the second, London: T. Cadell I823, http://urn.fi/URN:NBN:fi-fd2010-000032I3 (hämtad 3I/I 202I). 
När Frans Michael Franzén och hans reskamrat Carl Bremer i maj I795 stod i färd att lämna Åbo för att resa till Europa, tvingades de invänta gynnsamma vindar i hamnen på Beckholmen i flera dagar innan fartyget kunde avgå. I Korpo stod fartyget åter i hamn i väntan på gynnsamt väder. ${ }^{9}$ Långsamheten och väntandet var en uppenbar prövning för Franzén som led av resfeber. Framför sig hade han ett unikt äventyr - om bara fartyget skulle komma iväg!

I januari ı8o publicerade Franzén i Åbo Tidning, som han själv redigerade, första delen av en följetong där han i form av dagboksanteckningar skildrade början på sin resa. I följetongen återkom han också till de stämningar som rått på den lilla ön Fagerholm nära Korpo där resenärerna inväntat gynnsamma vindar. ”Mit tålamod pröfwas", skriver Franzén, och redogör för hur han fantiserade om att få se nya landskap med annan växtlighet, till exempel vinrankor. I verkligheten såg han inget annat än enformiga grynnor: "Dygn efter dygn förtråne wi redan i denna öde hamn, der klippan med tullhuset är en sann förargelseklippa för alla utrikesfarare från Åbo.” På ön fanns knappt någon växtlighet eller annat liv - med undantag av otaliga alfåglar - och inget annat att göra än att vänta. ${ }^{10}$ Enligt den lokala kvinna som tog hand om resenärerna skulle Magerholm varit ett lämpligare namn för ön än Fagerholm. ${ }^{11}$ När fartyget sedan kunde fortsätta färden, seglade det till Helsingør i Danmark, varifrån Franzéns resa fortsatte till Köpenhamn och därifrån via flera andra danska städer mot Kontinentaleuropa.

Samma år, i augusti 1795 , korsades Östersjön även av grevinnan Sophie Creutz, som reste från Finland till Holstein i sällskap av sin dotter och sin tjänarinna. Resans syfte var att besöka maken Lars Glansenstierna, som hade varit medlem av Anjalaförbundet och därför befann sig i landsflykt, och parets son som vistades hos fadern. Creutz

9. Hänvisningarna till Franzéns resedagbok är gjorda utifrån en publicerad utgåva: Frans Michael Franzén, Resedagbok I795-I796, i urval och med inledning av Anders Hernmarck, Stockholm: LTs Förlag 1977. Jag har även bekantat mig med originalet i Kungliga Biblioteket i Stockholm.

Io. Franzén skriver "allor", vilket jag har tolkat som alfåglar.

II. Frans Michael Franzén,"Antekningar under en Utrikes resa", Åbo Tidning 31/1 I8oI, s. 2, https://digi.kansalliskirjasto.fi/sanomalehti/binding/4I4922? page $=2$ (hämtad 3/I 2O2I). 
inledde sin resa i Jokela herrgård i Nastola där hon bodde, men avfärden över havet skedde från Ekenäs på ett handelsfartyg med destination Lübeck. Redan i början av resan blev det uppehåll, då vinden avtog vid Hangö och man tvingades vänta i över en vecka på att det skulle blåsa upp igen. Då resan äntligen kunde fortsätta fick Creutz uppleva ett för henne helt nytt element och en ny miljö - havet som både gungade och bar fartyget. Hon hade aldrig tidigare seglat, men verkar inte ha varit rädd för sjöresan. Snarare kände hon stolthet över sitt eget mod och över hur väl kvinnotrion klarade av resan. ${ }^{12}$

Under segelfartygens tidevarv var det ett slags äventyr bara att korsa Östersjön. Immanuel Ilmoni, som hade inlett sin Europaresa i juli I828, skrev i ett resebrev adresserat till sina vänner att färden från Åbo till Travemünde hade räckt sexton dygn. Under denna tid hade det lilla sällskap som reste med fartyget - och som att döma av Ilmonis brev bestod av män, i huvudsak finländare - hunnit roa sig bland annat med att sjunga, hitta på tokroliga hederstitlar till varandra, bada i tunnor och klättra i riggen. ${ }^{13} \mathrm{I}$ brevet får Ilmoni den långa resan över havet att framstå nästan som en lustfärd.

Förutom att erbjuda spänning och äventyr har färderna med segelfartyg visat för resenärerna hur begränsad människans fyndighet är inför nyckfulla vindar och det mäktiga havet. Franzén beskriver känslan av att vara beroende av vädrets makter hösten I796, då han tillsammans med reskamraten Bremer väntade på att kunna inleda resan hem i Orford i England. Det var vindstilla och resenärerna kunde inte göra annat än vänta, samtidigt som de i olika naturfenomen försökte läsa in tecken på att vindarna skulle vända. Franzén förhöll sig skeptisk, eller i alla fall halvt ironisk, till sjömännens väderprognoser:

Människan har hittat på att avleda åskan, men ännu har hon intet lärt att ändra vår Herres väder, och aldrig lär hon gå så långt. Därföre äro sjömän vidskepliga, därföre ha vi till och med halvt på skämt och halvt på allvar lyssnat till allt skrock vi få i oss, som kan föröka vårt

I2. Kirsi Vainio-Korhonen, Sophie Creutzin aika. Aateliselämää I7oo-luvun Suomessa, Helsinki: Suomalaisen Kirjallisuuden Seura 2008, s. 185-194.

I3. Ilmonis brev daterat i Hamburg I9/8 I828. Immanuel Ilmoni, Fem resebref frän kontinenten af Immanuel Ilmoni I828-I830, med några belysningar af J.O.I. Rancken, Vasa: F. W. Unggrens boktryckeri I894, s. I-2. 
hopp om vind. Ibland gå vi i land för att göra vind, ibland dricka vi Västans skål. Nej, säger en annan, Östan blir stött om vi aldrig dricka hans, och blir kvar i hamnen. Än fly vi till tupparne däruppe och lyssna till deras galning och hålla dem som profeter. ${ }^{14}$

En sjöresa var beroende, förutom av ett dugligt fartyg och en kompetent besättning, av faktorer inför vilka de hjälplösa passagerarna endast kunde hoppas, be och vänta. Trots seglingsteknologins utveckling hade den här oförutsägbarheten i årtusenden varit en oskiljaktig del av sjöfarten.

\section{SJÖRESORNAS NYA TEKNOLOGI}

I början av I80o-talet förändrades resandet på haven då ångkraften introducerades. Redan i början av I820-talet trafikerade det svenska ångfartyget Stockholm oregelbundet mellan Stockholm och Åbo. Det första finländska ångbåtsbolaget, det 1836 grundade Åbo Ångfartygs Bolag, öppnade reguljärtrafik på samma rutt och trafikerade snart också rutten mellan Åbo och S:t Petersburg - med Helsingfors och Reval som mellanhamnar. ${ }^{15}$ Från Finland kunde man i början av seklet ändå inte resa direkt till Kontinentaleuropa. Ilmoni, som gjorde en lång Europaresa vid decennieskiftet I830, korsade Östersjön med segelfartyg men kunde senare under resan bekanta sig med nyare reseteknologi genom att färdas med ångfartyg i Sydeuropa. Trots detta ersatte de tidiga ångfartygen inte på kort sikt segelfartygen, särskilt inte på längre havsrutter eller i frakttrafiken. De lämpade sig framför allt för passagerartrafik på skyddade farleder.

På 1840-talet kunde man resa med ångfartyg till Tyskland från Sverige eller Danmark. Mathilda Rotkirch och Johan Vilhelm Snellman, som reste i början av årtiondet, steg båda ombord på ångfartyg i Stockholm därifrån resan gick till Kontinentaleuropa. Rotkirchs sällskap avreste i maj I840; i sin resedagbok skriver hon egentligen inget om själva resan, hon nämner endast fartygets namn som var

I4. Franzén, Resedagbok, s. 236-237.

15. Sven Andersson, De första ångbåtarna Åbo-Stockbolm. Ett hundraårsminne, Meddelanden från Sjöhistoriska museet vid Åbo Akademi 2, Åbo: Åbo Akademi 1936. Texten är ett särtryck ur Åbo Underrättelser i936, nr 288. 
Svithiod. ${ }^{16}$ Det ifrågavarande fartyget var en 1837 byggd hjulångare som trafikerade rutten Stockholm-Kalmar-Ystad-Rostock-Lübeck, den första reguljära rutten för passagerartrafik mellan Sverige och Kontinentaleuropa. ${ }^{17}$ Tack vare rutten var det möjligt för Rotkirch att från Stockholm nå Lübeck på tre dagar.

Samma år, i augusti I840, avreste Snellman från Stockholm mot Kontinentaleuropa med ett annat ångfartyg, postångaren Sverige. Snellmans färd gick inte direkt till den tyska kusten utan till Danmark, där han besökte Köpenhamn innan han fortsatte resan till Tyskland. Om sin upplevelse av denna resa skrev han boken Tyskland, skildringar och omdömen frän en resa I840-I84I, som publicerades i Stockholm 1842. Reseskildringen inleds med en beskrivning av en ångbåtsfärd:

I det skönaste väder, en ännu sommarvarm Augustimorgon, sköt det vackra ångfartyget Sverige plaskande in i Sundet, förbi de glänsande kritklipporna vid Stevensklint på ena sidan och Falsterbo-ref, med dess fyrbåk, på den andra. Resan ifrån Stockholm och Carlskrona, som besöktes på en liten stund, hade, på ungefär 32 timmar, gått trefligt och i ärligt Svenskt sällskap. Endast då vi angjorde Carlskrona, blåste vinden upp och hotade med en stormig natt. ${ }^{18}$

Från Karlskrona fortsatte färden ännu samma kväll mot Köpenhamn. I sin reseskildring förmedlar Snellman en idyllisk ögonblicksbild av den här kvällen. Han beskriver ett lugnt böljande hav och en stjärnklar himmel - och hur sång till gitarrackompanjemang hördes från akterdäck. ${ }^{19}$ Stämningen var avslappnad - eller så beskriver Snellman den i alla fall. I denna skildring representerar havet inte ett hot eller en risk, utan är snarare en vacker kuliss för en angenäm erfarenhet.

I6. Mathilda Rotkirch,"Journal skrifven af M. Rotkirch under en resa genom Tyskland, Italien och Frankrike åren I840 och I84I", Jouni Kuurne (toim.), Mathilda Rotkirch. Taiteilija ja matkailija, [Porvoo]: Porvoon museo \& [Turku]: Turun taidemuseo 2002, s. 79 .

I7. Svithiod, Bo Palmqvists samling, Sjöhistoriska museet, Stockholm, https://digitaltmuseum.se/O2IOI5750766/svithiod (hämtad I5/12 2020).

I8. J.V. Snellman, "Tyskland, skildringar och omdömen från en resa I840-ı84I", J.V. Snellman, Samlade arbeten III: $1842-1843$, Kari Selén (red.), Helsingfors: Statsrådets kansli i993, s. 3 .

I9. Ibid., s. 3 . 
Den angenäma upplevelsen torde vara det utmärkta vädrets, men också det pålitliga postfartygets förtjänst.

Snellmans resa fortsatte senare från Köpenhamn till Kiel, som kunde nås på ungefär nitton timmar. Den här gången färdades han med ett danskt ångfartyg som avgick på eftermiddagen och tog sig mot destinationen genom natten. ${ }^{20}$ Ångmaskinerna gjorde resandet till havs mera förutsägbart. Ångfartygen höll en jämn hastighet och därmed kunde Snellman registrera de sjöresor han gjort med timmars precision. Till skillnad från resenärer som tidigare färdats med segelfartyg kunde han lita på att fartyget skulle nå Kiel på knappt ett dygn, utan att behöva be om gynnsamma vindar. Riktigt så exakt trafikerade ändå inte ångfartygen alla gånger. Det var känt att det redan nämnda ångfartygsbolaget i Åbo hade svårigheter att hålla tidtabellerna på grund av att fartygen drabbades av tekniska fel eller överraskades av exempelvis stora isflak som flöt omkring i havet. ${ }^{21}$

På I850-talet blev det möjligt att resa direkt till Tyskland också från Finland, då propellerfartyget Hengist som gick med ångkraft började trafikera rutten till Lübeck, turvis från Helsingfors och Åbo. Med detta fartyg korsade Zacharias Topelius Östersjön när han påbörjade sin tio veckor långa Europaresa. Utifrån sina erfarenheter av resan publicerade han 1856-I857 artikelserien "Söder om Östersjön" i Helsingfors Tidningar, vars redaktör han själv var. I inledningen till serien skildrade han sina känslor inför avfärden och ångfartygets snabba framfart. Strändernas landskap förändrades på ett ögonblick då fartyget skred framåt i hög hastighet. En likadan avfärd hade sannolikt också Franzén önskat sig inför sin resa. Ångfartygens avfärd var inte förknippad med samma tvekande och väntande som segelfartygens. Efter att fartyget hade lämnat hemlandets stränder bakom sig kunde Topelius koncentrera sig på att skildra stämningarna:

Långt bakom oss dånar återljudet af Sweaborgs kanoner. Den nyss blokerade hamnen öppnar sin trånga port; de tunga bergen wika tillbaka; det blåa glänsande hafwet utbreda sig omäteligt för wår syn i wårsolens sken, och frihet andas öfwer dess salta wågor. ${ }^{22}$

2o. Ibid., s. 9 .

21. Andersson, De första ångbåtarna, s. 4, 7 .

22. Zacharias Topelius, "Söder om Östersjön", Helsingfors Tidningar $24 / 9$ I856, s. 2, 
Efter att havet hade korsats fortsatte resorna i Kontinentaleuropa i början av I8oo-talet i huvudsak längs landsvägar, även om också flodrutter utnyttjades. En av de viktigaste transportformerna före järnvägen var postvagnarna, ett sätt att resa som i början av I80o-talet var helt annorlunda organiserat än den fartygstrafik som gick över Östersjön. Även om inte heller postvagnarna i första hand hade funktionen att transportera passagerare var detta trafiksystem anmärkningsvärt välutvecklat. Med sina reguljära rutter, fasta tidtabeller och hållplatser på gästgiverier kan postvagnsnätverket ses som ett egenartat teknologiskt system. En viktig förutsättning för trafikformens utveckling var självklart dugliga landsvägsnätverk, och sådana hade under I70o-talets lopp utvecklats i delar av Europa.

Att färdas med häst och vagn var självklart i sig ingen ny upplevelse för finländska resenärer. Däremot kunde man i Finland inte stifta bekantskap med ett lika välorganiserat trafiksystem som postvagnsnätverket i Kontinentaleuropa. Innan postvagnsnätverket började utvecklas på I6oo-talet hade resenärer varit tvungna att separat komma överens om varje vagnskjuts - alternativt måste resenären vara tillräckligt förmögen för att kunna röra sig med egen vagn. Med introduktionen av postvagnarna kunde resenärerna däremot börja förlita sig på att systemet fungerade och att resorna framskred planenligt. Uppehållen mellan de olika etapperna var exakt angivna, inklusive hästbyten. Också resornas kostnad var rimlig, vilket gjorde systemet tillgängligt för allt fler kundgrupper. ${ }^{23}$ Postvagnarna utnyttjades av resenärer från olika samhällsskikt, såväl män som kvinnor.

Sett från ett nutidsperspektiv framstår resandet med häst och vagn som ett långsamt och mödosamt sätt att röra sig över långa avstånd. Som längst färdades resenären med vagnskjuts genom hela den europeiska kontinenten - från norra Tyskland till södra Italien förvisso via många mellanetapper. I samtiden var postvagnarna ändå

https://digi.kansalliskirjasto.fi/sanomalehti/binding/50778r?page=2 (hämtad 3/r 202I).

23. Klaus Beyrer, "The mail-coach revolution: Landmarks in travel in Germany between the seventeenth and nineteenth centuries", German History 24, 2006:3, s. 375-376, https://doi.org/Io.IIgI/o266355406gh379oa. 
kända som ett bekvämt och snabbt färdmedel. Franskans ord för postvagn, diligence, hänvisar bokstavligen till snabbhet och idoghet. De franska postvagnarna gjorde skäl för sitt namn. När Franzén i slutet av I700-talet reste genom det då av Frankrike behärskade Belgien, beskrev han upplevelsen på följande sätt:

Diligensen. Vilken skillnad ifrån de tyska postvagnarne! I början voro vi blott fem, sex personer, men de växte på gatan och straxt vid staden och i Mecheln, så att vi till slut voro tio personer på en enda vagn, som drogs av sex hästar. Hade det varit rum, så skulle sällskapet ökats ännu mer. Dock sutto vi bekvämare än i de gemena tyska vagnarne. ${ }^{24}$

På I7oo-talet introducerades i Kontinentaleuropa den snabba extraposten, på tyska Extrapost, där priset för passagerarplatser var högre än på de ordinära postvagnarna. ${ }^{25}$ Ilmoni, som reste från Hamburg till Berlin med extrapostvagn I828, var nöjd med upplevelsen - den snabba, punktliga och bekväma skjutsen var enligt honom värd det högre priset. ${ }^{26}$ Kring sekelskiftet 1800 och under de därpå följande decennierna var postvagnsnätverket ett långt utvecklat trafiksystem som för många resenärer i praktiken var det enda sättet att resa längre sträckor till lands.

Effektiviteten till trots hade postvagnarna också brister. Även om vagnens bänkar var försedda med vadderade sittdynor var det en bedövande upplevelse att resa i flera timmar eller dagar - eller, som Snellman uttrycker saken:"sedan man suttit tvenne dygn i vagn, blifva äfven ressortdynor hårda." 27 I praktiken varierade vägarnas skick och passagerarna tvingades utstå skakningar och gupp. Enligt Mathilda Rotkirch blev resan i vagn från Lübeck till Hamburg en ansträngning då vägen var i dåligt skick: "[P]å en så dålig väg har jag aldrig rest", skrev hon i sin dagbok. ${ }^{28}$ Sommartid kunde det också vara hett i de slutna vagnarna. Även andra faktorer, som medrese-

24. Franzén, Resedagbok, s. IoI.

25. Beyrer, "The mail-coach revolution", s. 377-380.

26. Ilmonis brev daterat i Hamburg I9/8 I828. Ilmoni, Fem resebreffrån kontinenten, s. II.

27. Snellman, "Tyskland", s. I6.

28. Rotkirch,"Journal skrifven af M. Rotkirch", s. 79 . 
närernas störande parfymlukter eller högljudda snarkande, ${ }^{29}$ kunde förstöra stämningen.

De hästdragna vagnarna utgjorde ett intimt rum, där passagerarna fysiskt kom varandra väldigt nära. Någon privat sfär ingick inte i detta sätt att resa. I bästa fall kunde man i postvagnarna prata politik, skämta och göra roliga bekantskaper - Snellman skriver om flera sådana upplevelser - men likväl hände det ibland att en mängd resenärer delade vagn utan att riktigt hitta en gemensam ton. Eller för den delen ett gemensamt språk, något som Ilmoni fick uppleva då han reste i en tysk postvagn i ett sällskap där bara några få kunde tyska medan de övriga endast talade engelska eller franska. Engelska och franska hörde inte till de språk Ilmoni behärskade flytande, men trots detta försökte han artigt delta i diskussionen som böljade från väder och vind till postverket och Napoleons förehavanden. ${ }^{30}$

En erfarenhet som alla som färdades i postvagnarna sannolikt delade var den ständigt närvarande tröttheten. Postvagnarnas effektivitet grundade sig delvis på att de rörde sig också nattetid och det var inte alltid lätt att sova i dem. I sitt verk Tyskland skriver Snellman om de nattliga färderna och om hur passagerarna ofta anlände till en ny ort under dygnets mörka timmar då det inte var möjligt att få en uppfattning om omgivningen. I vissa fall trafikerade vagnarna genom hela natten och gjorde uppehåll först på morgonen. Efter en natt i postvagnen var resenärerna trötta vid ankomsten till följande stad. Under uppehållet på omkring en timme kunde de äta frukost. ${ }^{31}$ Efter en kort vilopaus var det dags att stiga ombord på nästa vagn igen. I ett brev som Snellman under sin andra Europaresa I847 skrev till hustrun Johanna Lovisa Snellman skildrar han vedermödorna med att färdas med postvagn på följande sätt: "Vagnsdynor och ryggstöd äro som våra förmakssoffor, men af ovana rådbråkas man dock af att

29. Dessa störande moment nämner Bernhard Crusell i sin dagbok från en resa $\mathrm{i}$ Frankrike I803. Bernhard Crusell, Keski-Euroopan matkapäiväkirjat I803-I822, suomentanut ja toimittanut Janne Koskinen, Helsinki: Suomalaisen Kirjallisuuden Seura 20Io, s. I26.

30. Ilmonis brev daterat i Hamburg $19 / 8$ I828. Ilmoni, Fem resebreffrån kontinenten, s. II-I2.

3I. Snellman, "Tyskland", s. I5. 
sitta 30 timmar och skallra, utan annan hvila än $1 \frac{1}{2}$ timme för middag, 20 Min quällsvard och frukost kaffe." ${ }^{2}$

Låt oss ännu för en stund återvända till hästvagnarnas tekniska sida, som i sig är högst enkel. Vagnarnas centrala beståndsdelar var hjulen och hästkrafterna, utan vilka det inte skulle ha varit möjligt att ta sig från ena sidan av Europa till den andra. Hästarna - liksom även åsnor och mulåsnor - var således livsviktiga inslag i detta system som gjorde det möjligt att färdas längs landsvägar och bergsstigar. Före ångkraftens intåg var hästen en motor, en maskin som man ofta använde så länge det gick - sådana slutkörda hästar såg Franzén särskilt i storstaden Paris. ${ }^{33}$ Resenärerna uttryckte även medkänsla för djuren. Under en vandring i de tyska bergen tyckte Snellman synd om de små åsnor som anlitades för färden och ondgjorde sig över en präst som täcktes rida på en åsna i stället för att använda sina egna ben för att bestiga berget. Samtidigt noterade Snellman med glädje hur väl de hästar som drog postvagnarna behandlades i Tyskland. De piskades nästan inte alls, och togs även väl om hand under uppehållen. ${ }^{34}$

\section{TIDIGA UPPLEVELSER AV TÅgRESOR}

Om någon sade dig, goda Betty, när du en middag i sommarhettan åker stora landswägen från Helsingfors till Tawastehus - när hästarna digna af trötthet, pisken beständigt hwiner, wagnen framstrider fot för fot uppför en sandig backe, natten kommer innan du hinner målet, emedan du så sent kom ut från förmiddagskaffet, och du är twungen att söka en owan bädd på en rustik gästgifwargård - om någon då sade till dig, att detta bråk snart nog är öfwerflödigt, att du i en framtid skall åka denna samma wäg på twå timmar, utan fruktan af solens hetta, det hotande åskmolnet, wägens damm och hållkarlars hojtande $[\ldots]^{35}$

32. "J.V. Snellman - J.L. Snellman 27/7 I847", J.V. Snellman, Samlade arbeten V: $1845-$ I847, Kari Selén (red.), Helsingfors: Statsrådets kansli i995, s. 702.

33. Franzén, Resedagbok, s. I35.

34. Snellman, "Tyskland", s. I8, 4I.

35. Zacharias Topelius, "Söder om Östersjön", Helsingfors Tidningar 8/10 I856, s. 2, https://digi.kansalliskirjasto.fi/sanomalehti/binding/513637?page=2 (hämtad 3/I 202I). 
Så här skrev Topelius I856 till den fiktiva Betty som hans berättelse om Europaresan var riktad till. Skildringen ger ingen rosig bild av att färdas med häst och vagn - men hans syfte här var framför allt att förbereda läsaren inför tågresor. I Kontinentaleuropa hade Topelius nämligen själv haft möjlighet att resa med tåg, den nya epokens färdmedel. I Finland framstod denna trafikform ännu på i850-talet som ett framtidsscenario, som resenärer på de dammiga landsvägarna bara kunde drömma om.

I början av i840-talet, vid tidpunkten för Mathilda Rotkirchs och Snellmans resor, var det redan möjligt att uppleva tågresor, om än tills vidare på relativt korta sträckor. Upplevelsen var unik, eftersom såväl Finland som Sverige ännu på 1840-talet saknade järnvägar. Med beaktande av detta skriver både Rotkirch och Snellman förvånansvärt lite om den nya reseteknologin, som inom kort i grunden skulle förändra såväl resandets natur som människans relation till tiden. Ibruktagandet av ångkraften både till lands och till havs förde med sig exaktare tidtabeller än tidigare. Förvisso hade också postvagnarna bestämda avfärdstider, men de tidiga tågen rörde sig tre gånger snabbare än postvagnarna. Tågtrafiken ledde till att tidtabellerna måste preciseras, vilket också gjorde det nödvändigt att närmare fastställa i vilken tid man levde på respektive ort. Den standardiserade tiden är en I80o-talsuppfinning, även om indelningen av världen i tidszoner skulle ske först i slutet av seklet och olika länder anslöt sig till den gemensamma tiden i olika takt. ${ }^{36}$ Ibruktagandet av ångkraften inom reseteknologin är ett belysande exempel på hur en innovation med tillämpningar har resulterat i genomgripande kulturella förändringar.

Att Rotkirch och Snellman inte kommenterar sina upplevelser av att resa med tåg är anmärkningsvärt, särskilt som Wolfgang Schivelbusch, som redan på 1970-talet intresserade sig för tågresandets historia och är en auktoritet på området, framhållit att det nya färdmedlet förändrade människornas uppfattningar om tid och rum. Tågen associerades även med olika rädslor som bland annat väcktes av de

36. Wolfgang Schivelbusch, Junamatkan historia, suomentanut Margit Heinämäki, Tampere: Vastapaino I996, s. 33-37, 4I-42; Hannu Salmi, "Rautatieasemalla ja junassa”, Leila Koivunen, Taina Syrjämaa \& Ilse-Mari Söderholm (toim.), Turistin tilat. Tilallisuus modernin matkustajan kokemuksena, Turku: Turun Historiallinen Yhdistys 2006, s. 26-27. 
höga hastigheterna och av att befinna sig i en sluten vagn. Rotkirch nämner i sin dagbok endast att sällskapet också färdades med tåg, medan Snellman i skildringen av sin resa åren I840-I84I redogör för restiderna mellan olika stationer. Skulle denna tysthet kunna bero på att bansträckorna i början av I840-talet var så få att järnvägen ännu inte framstod som den symbol för framsteg och modernisering som den något senare skulle bli? I början av I840-talet förkortade järnvägslinjerna inte märkbart restiden för resenärer på längre rundresor - och således förändrade tågen inte upplevelsen av resandet i ett bredare perspektiv.

Mera detaljerat skildrar Snellman sina tågresor först i samband med sin andra resa till Europa I847, då järnvägsnätverket hade byggts ut och var betydligt längre än i början av årtiondet. Under resan skrev Snellman flera brev till sin hustru i Kuopio, i vilka han redogjorde för resandet med tåg på följande sätt:

På en sådan bana framföres man af en ångvagn, hvilken utom de vanliga hjulen har två stora hjul, som kringföras af ångkraften, och hvilken vagn kan släpa efter sig en Io st stora vagnar med plats för 30 personer i hvarje, d. ä. med 300 personer, och deras effekter. Det går så lätt, emedan hjulspåren bestå af jernskenor, och vagnarnes hjul likaså af jern. ${ }^{37}$

Brevet avspeglar Snellmans läraraktiga stil då han upplyser sin hustru om ångkraftens förmåga att få tåget med passagerare i rörelse. För en person bosatt i Kuopio kan det ha varit svårt att föreställa sig vagnar som kunde transportera hela 300 passagerare på en gång.

Om sina upplevelser under resan skrev Snellman också i den tredelade artikelserien "Paris och London" som publicerades i Litteraturbladet i slutet av i847. I serien jämförde Snellman sina erfarenheter av att resa med tåg i olika länder - i slutet av i840-talet hade järnvägsnätverket redan expanderat så mycket att en jämförelse var möjlig. I Tyskland var vagnarna bekvämast och ordningen exemplarisk. I Frankrike var verksamheten mera sorglös och passagerarna åtnjöt

37. "J.V. Snellman - J.L. Snellman $27 / 7$ I 847 ", s. 702. 
fler friheter. I England fick var och en i sin tur klara sig enligt bästa förmåga:

I England är var och en lemnad åt sig sjelf. Vill ni springa i banan under vagnarnes hjul, så står det er fritt. Vill ni icke hålla reda på de olika trainerna, stationerna för vagnombyte, er sjelf och era effekter, så får ni också skylla er sjelf, om ni kommer till Glasgow i st f. Liverpool, sjelf anländer till Hull, under det er kappsäck går till Birmingham, om ni får söka tillsamman era afryckta armar och ben eller också vandrar all verldens väg, krossad under de bangården korssande trainerna. "Help yourself and God will help you"! synes vara allmänna valspråket. Förmynderskap tåls icke och behöfves icke. ${ }^{38}$

Textens stil är på ett för Snellman typiskt sätt ironisk, men torde bottna i genuin förargelse - kanske kände han sig aningen vilsen på de brittiska järnvägsstationerna. I ett brev till hustrun skrev han hur som helst att livet på de engelska järnvägarna var farligt - "olyckor hända alla veckor". ${ }^{39}$ Tonen hade knappast en lugnande effekt på hustrun, som troligtvis redan från förut oroade sig för sin resande make.

Utbyggnaden av järnvägsnätet framskred snabbt. Där Snellman i början av I840-talet bara hade kunnat prova på att resa med tåg konstaterar han i slutet av årtiondet att det nu är möjligt att resa i stora delar av Europa med ångkraft. Följande brev skrev han i småstaden Neustadt Eberswalde i Tyskland:

Härifrån kan man nu, på en I2 mil när, komma till Rheinfloden på jernväg, utför den på ångbåt, från staden Köln på jernväg genom hela Belgien och genom Frankrike till Paris, derifrån åter jernväg till hafvet, öfver till England på ångbåt, öfverallt nästan i England på jernväg och tillbaka till Hamburg på ångbåt. För hela den färden behöfvas således hästar endast på sagde I2 mil. ${ }^{40}$

38. J.V. Snellman,"Paris och London", J.V. Snellman, Samlade arbeten VI: I847-1849, Raimo Savolainen (red.), Helsingfors: Statsrådets kansli i996, s. 59.

39. "J.V. Snellman - J.L. Snellman 22/9 I847", J.V. Snellman, Samlade arbeten VI: I847-I849, Raimo Savolainen (red.), Helsingfors: Statsrådets kansli i996, s. 682.

40. "J.V. Snellman - J.L. Snellman 27/7 I847", s. 702. 
I Helsingfors Tidningar skrev Topelius på I850-talet att Finland var "snart det enda land i Europa som saknar en jernväg”. Han jämförde olikheten mellan landsväg och järnväg med skillnaderna mellan handskriven och tryckt text. På motsvarande sätt som boktryckarkonsten inte hade ersatt behovet av handskriven text skulle inte heller järnvägarna helt och hållet åsidosätta landsvägarna. Trots detta innebar båda innovationerna ett stort framsteg. I samma text reflekterade Topelius - uppenbart inspirerad av sina personliga upplevelser - över de förändringar som järnvägarna skulle föra med sig. De krympande avstånden skulle föra människor och nationer närmare varandra, men även ge upphov till en ny tidsuppfattning och en ny känsla av brådska. Snälltågen rörde sig med vindens hastighet, förklarade Topelius för sina läsare. Han beskrev också detaljerat vagnarnas inredning - med sina soffor och gardiner påminde de enligt honom om en kammare, även om passagerarna i tredje klass förvisso satt på träbänkar. Den slutsats Topelius drar är följande:"Med ett ord, man reser icke, efter det begrepp wi göra oss om resor, man bor uppå jernwägarna." ${ }^{41}$ Förutsatt att man hade hunnit till rätt avgång och köpt en biljett kunde man resa i lugn och ro, utan de störande faktorer som kännetecknade resandet i hästvagn: "Intet regn, intet damm, intet qwalm, ingen fruktan för hästar och wagnshjul, diken och grindar, tjufwar och prejare - -." ${ }^{42}$

Topelius saknade alltså inte hästskjutsarna utan välkomnade med glädje den förändring som järnvägen innebar. Ett avstånd till tiden då man reste med häst och vagn kunde kanske ha medfört ett mera nostalgiskt förhållningssätt. Yrjö Hirn, som i början av r9oo-talet skrev om postvagnarnas historia, kunde redan romantisera vagnarna som för honom representerade ett betydligt mer poetiskt sätt att resa än tågen som rörde sig längs spikraka skenor. ${ }^{43}$ De som hade upplevt att resa med häst och vagn hade däremot en avsevärt mer mångfasetterad relation till trafikformen. De hade fått uppleva de dammiga och leriga vägarna och det långvariga sittandet som fick armar och ben att domna, liksom alla andra vedermödor som associerades med de hästdragna vagnarna.

4I. Topelius, "Söder om Östersjön", s. 2.

42. Ibid.

43. Yrjö Hirn, Vanhat postivaunut ja muutamia niiden matkustajia. Sterne, Moritz, Eichendorff, Borrow, Helsinki: Otava I926. 
I de långa rundresornas idé ingick att beskåda sevärdheter, ta del av kulturupplevelser och bekanta sig med en mångfald av besöksmål, från fattigvårdshus till industrianläggningar. En del besöksmål hade ankytning till resenärernas professionella intresseområden. Således besökte läkaren och naturvetaren Ilmoni olika sjukhus och deltog i en naturvetenskaplig konferens i Berlin. Den i Nystad födde musikern Bernhard Crusell bekantade sig i sin tur under sina resor i början av I80o-talet bland annat med nya innovationer i produktionen av pianon och nottryck. Båda hyste också intresse för tekniska tillämpningar och apparater överlag. Crusell besökte bland annat en gobelängfabrik och följde med de olika skedena i tillverkningen av krut. Han besökte även ett observatorium och fick möjlighet att bekanta sig med hur en astronomisk klocka fungerade. ${ }^{44}$ Många resenärer vid den här tiden var otröttligt intresserade av nästan allt mellan himmel och jord - ett intresse som också sågs som en bildad resenärs plikt.

Till det tidiga I8oo-talets uppfinningar hörde den elektriska telegrafen, som revolutionerade informationsförmedlingen. I Europa började telegrafnätverket byggas ut på I840-talet; i Finland kopplade den första telegraflinjen I855 samman Helsingfors med S:t Petersburg. Den elektriska telegrafen hade likväl en mindre känd föregångare, den så kallade optiska telegrafen som togs i bruk i Frankrike under revolutionsåren i slutet av I7oo-talet. Under ett besök i Lille 1795 hade Franzén möjlighet att bekanta sig med denna speciella uppfinning som han i sin dagbok endast nämner kort: "Vilket under för den som fann rörelserna av denna tryck-stång! Att tala på fingrarne över gatan som vi gjorde förr, i miniatyr det samma." ${ }^{45}$ Franzén hade rätt i att det handlade om ett slags teckenspråk.

Med beaktande av att den 1794 byggda telegraflinjen mellan Paris och Lille var den första i sitt slag, torde Franzén ha varit en av de första finländarna som stiftade bekantskap med innovationen. Telegrafen var ett kommunikationssystem utvecklat av den franske fysikern Claude

44. Crusell, Keski-Euroopan matkapäiväkirjat I803-I822. Verket innehåller Crusells resedagböcker från tre resor som han gjorde I803, I8II och I822.

45. Franzén, Resedagbok, s. I2O. 
Chappe (1763-1805) och baserade sig på rörliga plattor som fästes i ändan på master som placerades $i$ torn på höga höjder - troligen är det dessa som Franzén avser med termen "tryck-stång". Plattornas rörelser, det vill säga signaler, "lästes", vilket i praktiken innebar att de varseblevs med hjälp av ett teleskop från ett annat torn. På så sätt förmedlades meddelandet från en telegrafpunkt till följande. I mörker eller i dåligt väder var den optiska telegrafen oanvändbar. ${ }^{46}$

På resmålen har resenärerna tagit del av de mest varierande föreställningar, av vilka en del hade anknytning till vetenskapliga och teknologiska uppfinningar. Under sin vistelse i Berlin 1828 följde Immanuel Ilmoni med en uppvisning med varmluftsballong. Även om flygningar med varmluftsballong vid den här tiden redan hade gjorts $\mathrm{i}$ årtionden - mera exakt sedan $\mathrm{I} 783$ - var föreställningen ingen vardaglig upplevelse. Enligt Ilmonis eget vittnesmål steg ballongen till 3800 fots höjd, det vill säga en dryg kilometer, och dess hastighet överträffade hans förväntningar. Efter en kort flygfärd gjorde varmluftsballongen en landning och passagerarna såg enligt Ilmoni välmående ut. ${ }^{47}$

Även Snellman bevittnade under sin vistelse i Frankfurt I847 en färd med varmluftsballong. I ett brev som han sände till hustrun i Finland nämner han att ballongen var det"förnämsta" han sett i staden och förklarar högst detaljerat hur den fungerade. Hustruns kunskaper om fysik torde ha varit begränsade - kanske var brevet avsett att läsas upp även för barnen. Snellman förklarar i varje fall varför ballongen lyfter, hur stor den är (i samma storleksklass som guvernörsresidenset) och hur "Luftseglaren, en Engelsman Green (läs Grin) satt sjelf, så länge man kunde se, på tunbandet, i frack och hatt". Green var en erfaren "luftseglare" men enligt Snellman såg den ena passageraren, en engelsman, förskräckt ut. Den andra passageraren var lokal. Till tonerna av musik steg luftballongen i höjden:"Green svängde sin hatt till afsked och de båda andra sina fanor. Det var en oändligt vacker syn. Ballongen steg så jemnt och skönt." ${ }^{48}$ Kanhända fick Snellman

46. Patrice Flichy,"The birth of long distance communication. Semaphore telegraphs in Europe (I790-I840)", Réseaux. Communication - Technologie - Société I, I993:I, s. 8I-IoI, https://www.persee.fr/doc/reso_0969-9864_I993_num_I_I_3272 (hämtad 3I/I 2O2I).

47. Ilmoni, Fem resebreffrån kontinenten, s. I5.

48. "J.V. Snellman - J.L. Snellman I6/8 I847", s. 653. 
vid åsynen själv lust att stiga ombord på luftballongens gondol. I sitt brev skrev han:

Jag tänkte: så roligt det vore! Men det vore dock lättsinne, onödigt. Och min nästa tanke var: Hela min resa är mer, än jag bort göra; ty för Er, med Er mina älskade vill jag så gerna lefva. Att dö syntes mig förut så lätt; nu börjar tanken derpå kännas mig så tung, så tung. ${ }^{49}$

Ansvaret för familjen som väntade hemma tyngde, och rapporteringen om de märkvärdigheter han såg på vägen torde också ha orsakat dåligt samvete. Snellman är till sitt rykte allt annat än lättsinnig, men hans reseskildringar från I840-talet öppnar upp en annan sida av hans personlighet. Vi möter en Snellman som njuter av de speciella besöksmålen och storstädernas vimmel med de nöjen som fanns där. Kanhända steg han i sin fantasi till höjderna med varmluftsballongen - utan någon djupare orsak och enkom för att roa sig.

\section{Dioramats MAgi}

Till I80o-talets populära underhållningsformer hörde också panoramorna och dioramorna, visuella spektakel som inför åskådarna trollade fram illusioner av urbana och agrara landskap eller illustrationer av historiska händelser. Genom att erbjuda en möjlighet att se och uppleva ett främmande landskap eller en främmande plats, med förebild någonstans i världen, fungerade föreställningarna som ett slags substitut för resande. ${ }^{50}$ Panoramat och dioramat har likväl intresserat även personer som redan var på resande fot och genom dem kunde bekanta sig med nya landskap och besöksmål. Dessa visuella föreställningar har säkert också fascinerat genom att bjuda på en skickligt skapad efemär illusion, en särskild upplevelse som inte var möjlig på hemorten.

49. Ibid.

50. Om panoramats och dioramats virtuella dimension, se Leila Koivunen, Taina Syrjämaa \& Ilse-Mari Söderholm, "Kotona”, Leila Koivunen, Taina Syrjämaa \& Ilse-Mari Söderholm (toim.), Turistin tilat. Tilallisuus modernin matkustajan kokemuksena, Turku: Turun Historiallinen Yhdistys 2006, s. 9-II. 
Panoramat hade uppfunnits och patenterats 1787 av den irländskfödde målaren Robert Barker, som öppnade det första panoramat i London. Panoramat var en omedelbar succé och föreställningar erbjöds snart i flera städer. Den effekt som väckte fascination baserade sig på en enorm målning som förevisades på en buktad yta. För denna behövdes en särskild byggnad, i vars mitt publiken stod och betraktade landskapet. Genom att reglera ljuset och tona ner målningens gränser skapade man ett intryck av att åskådarna befann sig inne i landskapet - som om hade de levt en stund på en annan plats (och i en annan tid). ${ }^{51}$ När Bernhard Crusell vistades i Paris I803 beskrev han i sin resedagbok sin upplevelse av en panoramaföreställning: "Konsten består uti at representera för Åskådaren en Stad lika som om man sjelf vore på Stället och hade utsigten ifrån et högt Tak." ${ }^{2}$ Det panorama Crusell åsett föreställde staden Neapel med näromgivningar. Trakten kring Neapel var ett givet tema för ett panorama - staden med den närliggande vulkanen Vesuvius var ett populärt resmål bland Italienresenärer och också de som besökte de arkeologiska utgrävningarna i Pompeji reste via staden. Crusell beskrev föreställningen på följande sätt:

Man fördes upför en trappa till en sort rund pavillon öfvertäckt med en Kupa lik et stort parasoll - $\mathrm{i}$ stället för väggar utbredde sig rundt omkring den vackra staden, med sina environger. Vesuvius Herculanum etc - ju mera man betraktade desto större blef synvillan - Taflan var förträffl. målad, och de minsta partier, distancer, colorit etc. noga observerade. ${ }^{53}$

Senare, år I8II, reste Crusell bland annat till Dresden där han såg ett panorama som föreställde Wien och som enligt honom var rätt

5I. Koivunen, Syrjämaa \& Söderholm,"Kotona”, s. 9-Io; Erkki Huhtamo, Illusions in Motion. Media Archaelogy of Moving Panorama and Related Spectacles, Cambridge (Mass.) \& London: The Massachusetts Institute of Technology Press 2013, s. I-5, https://utuvolter.fi/permalink/358FIN_UTUR/Icgjmon/almag92204938140597I (hämtad I5/12 2020).

52. Bernhard Crusell,"Crusells resedagböcker", Sven Wilson (red.), Bernhard Crusell - tonsättare och klarinettvirtuos: hans dagböcker, studier i hans konst, verkförteckning, Kungliga Musikaliska Akademiens skriftserie 2I, Stockholm: Kungl. Musikaliska akademien 1977 , s. 63.

53. Ibid., s. 63 . 
skickligt utfört - han visste också berätta att det tagit hela tre år att färdigställa. ${ }^{54}$ Det fanns också mobila versioner av panoramat, i vilka en rulle med ett stort bildtyg spolades upp framför publiken.

Dioramat var en något senare uppfinning än panoramat, som det hade inspirerats av. Spektaklet hade utvecklats av de franska målarna Charles-Marie Bouton och Louis-Jacques-Mandé Daguerre, den senare också känd som utvecklare av den tidiga fotograferingsmetoden dagerrotypin. Dioramat var en blandning av målning, scenografi och teater - utan skådespelare. ${ }^{55}$ Genom att utnyttja olika tygskikt, glasplattor och ljus skapade man en impression av tredimensionalitet och rörelse för åskådarna. Publikläktaren kunde vara rörlig, och i vissa föreställningar tittade publiken in genom ett hål för att se landskapet. ${ }^{56}$

Det första dioramat öppnades i Paris I822, det andra i London därpå följande år. Till sitt tekniska förverkligande var dioramorna mer komplicerade än panoramorna, även om de praktiska tillämpningarna varierade på olika orter. ${ }^{57}$ Carl Wilhelm Gropius öppnade 1827 ett eget diorama i Berlin tillsammans med sina bröder. Ilmoni besökte Gropius diorama hösten I828, då det var tämligen nytt. Han skriver att han har sett föreställningar som visade interiören av en gotisk kyrka och staden Genua med dess hamn. Upplevelsen hade gjort intryck på Ilmoni som konstaterade att "illusionen är alldeles förvånande". ${ }^{58}$ Nästan tjugo år senare, år I847, åsåg även Snellman en dioramaföreställning av Gropius, en upplevelse som han beskrev på följande sätt:

Ett såkalladt Diorama af Gropius, mycket berömdt, besökte jag äfven denna gång. Man införes i en liten kammare, hvars två väggar bestå af förhängen. När detta upprullas, ser man ut i en stor sal, der man endast ser en enda stor målning på motsatta väggen, men icke kan se öfriga väggar, tak eller golf. I taket, derifrån ljuset nedfaller, äro anbragta färgade glas, genom hvilka åstadkommes solsken, morgon och aftonrodnad, skymning och månsken. Sålunda visas landskap

54. Ibid., s. 109-IIo.

55. Huhtamo, Illusions in Motion, s. 139-I40.

56. Koivunen, Syrjämaa \& Söderholm, "Kotona”, s. II.

57. Huhtamo, Illusions in Motion, s. I4I.

58. Ilmonis brev daterat i Hamburg $19 / 8$ I828. Ilmoni, Fem resebreffrån kontinenten, s. $15-16$. 
eller det inre af stora kyrkor, och illusionen är så stark, att man tror sig hafva verkligheten framför sig. ${ }^{59}$

Såväl panorama- som dioramaföreställningarna bestod förutom av de visuella effekterna även av andra element, som musik, rökeffekter och en berättarröst. ${ }^{60}$ Erkki Huhtamo, som har studerat dessa tidiga mediespektakel, beskriver uppfinningarna som en kombination av byggnad, vy och maskin. ${ }^{61}$ För åskådaren var föreställningen en helhetsupplevelse, vilket framgår av Snellmans detaljerade beskrivning:

Är det en kyrka, så ringer i skymningen en klocka till bön. Ljusen upptändas, och under orgelns högtidliga toner framvandrar en procession med tända facklor. Detta åstadkommes så, att målningen nedtill är dubbel, och då det främre exemplaret småningom borttages, framträda mennisko figurerna, under det att de ställen på den bakre målningen, som föreställa ljus och facklor, äro genomskinliga och upplysas bakom taflan. Då man sålunda får se allt större figurer och klarare fackelsken, så tycker man, att processionen kommer allt närmare. Det är utmärkt vackert. ${ }^{62}$

Panoramat och dioramat är exempel på de nya former av visuella medier som introducerades under I8oo-talets lopp. I likhet med filmen, det sena i8oo-talets stora visuella innovation, blev också panoramorna och dioramorna populära runtom i världen genom sin förmåga att tillfälligt föra publiken till en annan verklighet. Att för en stund kunna övervinna begränsningar i tid och rum torde ha varit en central del av den särskilda magi som associerades med panoramat och dioramat, precis som i filmen, en konstform som dessa uppfinningar var föregångare till. Att försjunka i virtuella verkligheter är ingalunda något som hör endast vår tid till!

59. "J.V. Snellman - J.L. Snellman i6/8 I847", J.V. Snellman, Samlade arbeten VI: I847-I849, s. 647 .

6o. Koivunen, Syrjämaa \& Söderholm, "Kotona”, s. ıо.

6r. Huhtamo, Illusions in Motion, s. I39.

62. "J.V. Snellman - J.L. Snellman I6/8 I847", s. 647. 
Hur förmedlade då resenärerna sina erfarenheter till andra? Detta kunde ske genom privat korrespondens eller anteckningar i resedagböcker som lästes upp för familj och vänner. I dessa fall delades reseupplevelserna framför allt i resenärerens egen närkrets, utan några ambitioner att nå en bredare läsekrets. Det tidiga I80o-talets skriftliga offentlighet i Finland var också tämligen begränsad. Exempelvis utkom i landet endast en handfull tidningar - fram till I820-talet endast i Åbo. Ett särfall utgjorde de skildringar som i första hand var riktade till en bredare publik, exempelvis Snellmans verk Tyskland som utkom i Sverige eller reseskildringar som skrevs för dagstidningar. Särskilt Snellman och Topelius nådde redan på 1840- och I850-talen en bredare bildad läsekrets genom sina tidningar.

När Topelius 1865 i Helsingfors Tidningar konstaterade att Finland snart var Europas enda land utan järnväg, tog han ställning för att tågresor inom en snar framtid skulle bli verklighet också i hemlandet. I samma artikel skrev han: "Det gör mig ondt att säga, men en sanning är det, att wi stå femtio år tillbaka i nästan allt som gör andra nationer rika och stora. ${ }^{{ }^{63}}$ Snellman hade lyft fram samma tanke i olika sammanhang, och även han utgick från sina egna reseupplevelser. Järnvägen kunde ses som ett konkret exempel på och en symbol för den modernisering som i bred bemärkelse väckte finländska resenärers uppmärksamhet när de rörde sig söder om Östersjön. Just 1840- och 1850-talen framstår som en tydlig brytpunkt som belyser hur såväl den tekniska som den sociala utvecklingen framskred i varierande takt i olika delar av Europa.

De förändringar som skedde i resandet under 180o-talets lopp vävdes samman med andra samhälleliga och kulturella förändringar.Tack vare järnvägsförbindelserna kunde man resa genom Europa avsevärt snabbare än tidigare med häst och vagn. Grand tour-resornas epok började vara förbi, samtidigt som den växande medelklassen började resa allt mer. Allt fler hade möjlighet att resa, men det var få som kunde tillbringa ett eller rentav två år på resande fot. I den här essän har jag behandlat en tidsperiod då sådana längre resor ännu gjordes.

63. Topelius, "Söder om Östersjön", s. 2. 
Det faktum att resandets teknologi, som omfattade rutter, färdmedel och tjänster, saknade ett fast system, särskilt i Finland, gjorde resandet till ett egenartat äventyr. Samtidigt har en lång rundresa i Europa också varit en fysiskt ansträngande erfarenhet. De i hästdragna vagnar tillbringade timmarna och dagarna har säkert känts i kroppen - för att inte tala om exempelvis korsandet av Alperna, ett tema som jag $i$ det här sammanhanget inte har haft möjlighet att behandla.

Trafiksystemens utveckling gjorde resandet vardagligt, men samtidigt mer diversifierat: det var inte längre nödvändigt att se och uppleva allt under en och samma resa, som man ofta försökte göra i början av I80o-talet. När man begav sig iväg på en resa gjorde man det grundligt, vilket innebar att man bekantade sig med allt från balett och panoramor till bergsklättring och hälsobad. Och när fartyget på hemresan närmade sig Finlands kust kunde en betydande del av resenärerna vara säkra på att de inte skulle företa sig en motsvarande resa en andra gång.

Översättning till svenska av Johanna Wassholm 